International Journal of Economics, Business and Management Research

Vol. 6, No.02; 2022

ISSN: $2456-7760$

\title{
The Impact of the Disclosure of Integrated Business Reports on the Financial Performance of Shareholding Companies Listed in the Palestine Exchange
}

\author{
Ayah A. S. Haddad ${ }^{1}$, Firas S. Q. Barakat ${ }^{2}$, Ooroubah Mahmoud ${ }^{3}$ \\ ${ }^{1}$ Accountant, Administrative \& Financial Department, Al-Quds University, Palestine \\ ${ }^{2}$ Department of Accounting, Faculty of Economics and Business Al-Quds University, Jerusalem, \\ Palestine \\ ${ }^{3}$ Department of Banking \& Finance, Faculty of Economics and Business Al-Quds University, \\ Jerusalem, Palestine \\ Corresponding Author: Ooroubah Mahmoud \\ Email of Corresponding Author: omahmoud@staff.alquds.edu
}

DOI: $10.51505 /$ ijebmr.2022.6217

URL: http://dx.doi.org/10.51505/ijebmr.2022.6217

\begin{abstract}
The aim of this research is to identify the impact of the disclosure of integrated business reports on the financial performance of shareholding companies listed in the Palestine Exchange (PEX). The research population encompasses all Palestinian companies listed as of end of 2020 which total 47 companies. However, one investment company, namely Al-Aqariya Trading Investment Co. was omitted, as the data necessary to measure and calculate research variables was either unavailable or incomplete. The researcher collected data using a customized index specifically designed for this purpose that is based on previous research indices after revision and improvement. The index was developed in accordance with the study matter and content of integrated reports as stipulated by the International Integrated Reporting Council in its integrated reporting (IR) framework and consists of the eight main elements of integrated reports. The study concluded that there is no significant statistical impact for integrated reporting disclosure on the financial performance measured by the return on Assets (ROA) of the Palestinian companies listed in the PEX. It concluded that there is a statistically significant impact for integrated reporting disclosure on the financial performance measured by the return on equity (ROE) of the Palestinian companies listed in the PEX, and a statistically significant impact for integrated reporting disclosure on the financial performance measured by the earnings per share (EPS) of the Palestinian companies listed in the PEX
\end{abstract}

Keywords: Accounting disclosure, business integrated reporting, disclosure of business integrated reporting, financial performance.

\section{Introduction}

Despite great technological advancements that helped facilitate communication and provided massive software storage programs and databases, most companies still continue to keep information to themselves and only disclose the most significant financial information. Various 


\section{International Journal of Economics, Business and Management Research}

Vol. 6, No.02; 2022

ISSN: $2456-7760$

studies concurred that non-financial information is just as important to investors as financial information, as it reiterates and enhances transparency and reliability and helps to better predict future performance, share prices and evaluate the company's performance which consequently leads to more sound decision-making (Eccles et al., 2014).

Integrated corporate reporting represents a comprehensive and integrated picture of both the company's financial performance and sustainability, according to recommendations and a definition of the King III Report in South Africa (Ibrahim, 2019). Integrated reports essentially aim to create value for the enterprise itself, its shareholders, and other stakeholders, as they seek to take into account the six types of capital identified by the International Integrated Reporting Council (IIRC) that includes financial, manufactured, human, natural, intellectual, social and relationship capital. These six forms of capital constitute the foundation on which the activities of any enterprise are based by creating interrelated models that operate in unison to deliver enterprise activities. Hence, they are of utmost importance in evaluating the actual long-term performance of a company (IIRC, 2015).

This study seeks to identify the impact of integrated reporting disclosure on the financial performance of shareholding companies listed in the PEX. The study will identify the integrated reporting disclosure status of Palestinian companies listed in the PEX in 2020. The study will examine the impact of IR disclosure on the company's financial performance measured through return on assets (ROA), return on equity (ROE) and earnings per share (EPS). This study was implemented using 2020 data as the subject of study is new, particularly in developing countries and it is also not binding to any specific law or standard. The researcher believes that it is not possible to apply the research to previous years as integrated reporting disclosure was not available in company data and financial reports or it was otherwise only partially available. Moreover, most previous research that addressed the topic of integrated reporting is recent and only covers the period between 2015 and 2020 .

The article shall comprise the following.

The second section shall present the literature and describe the evolution of the research hypotheses. The third section shall describe the research methodology. The fourth section shall present the main findings. Finally, the fifth section shall present the conclusions and limitations.

\section{Literature Review (framework)}

The financial crises of the past decades had an adverse impact on the entire world. Consequently, countries in different parts of the world sought to improve the quality of financial reporting. These initiatives intensified following the 2008 global financial crisis in which many international banks went bankrupt. Various reform models shared one common goal, namely improving the quality of disclosures in a manner that benefits all sectors of society including shareholders, the market, labor force, companies and society in general. These benefits include enhancing the companies' sustainability, reputation and legitimacy, which is gained by disclosure of future projections, environmental assessments and other matters (Buallay, et al. 2020). 


\section{International Journal of Economics, Business and Management Research}

Vol. 6, No.02; 2022

ISSN: $2456-7760$

Established in 2010 in the United Kingdom, the International Integrated Reporting Council (IIRC) consists of a committee of investors, companies, managers, and members of the International Federation of Accountants (IFAC), the International Accounting Standards Board (IASB), the World Business Council for Sustainable Development (WBCSD) and the Global Reporting Initiative (GRI) which developed the general integrated reporting framework as a globally accepted framework (Sha'aban, 2019). Subsequently, there was an increase in the number of integrated reports all across the globe and particularly in the Middle East (Buallay et al., 2020). IIRC also provides a global database for publishing company reports that follow its general framework, which enables companies that intend to publish their first integrated report, as well as companies that seek to improve their reports by benefiting from this database (Burke, Clark, 2016). The general objective of these integrated reports is to help investors and analysts assess a given company's ability to create value and preserve this value over the short, medium and long term.

The quantitative information framework of integrated reports is broader and more comprehensive than descriptive data that can be measured, verified and compared as much as possible, which improves the quality of information and the ability to predict the company's future performance, thereby helping investors to make decisions and enabling the company to efficiently distribute available resources. Thus, these reports constitute an alternative to sustainability reports (Bouma, 2015).

Hence the idea was born of preparing one comprehensive report that includes all reports issued by a company based on the concept of "integrated thinking." Some believe that the idea of integrated reports dates back to 1994 and the principle of triple bottom line (TBL), proposed by a researcher. Attempts to prepare and issue integrated reports first took place in 1989, when the National Bank of Canada issued a sustainability report that included a section on social responsibility (Mohammad Abdul Jaleel, 2018; Yousef, 2015: Eccles, Saltman, 2011).

Finally, IIRC was established in 2010 to develop a systematic framework for integrated reporting supporting the long-term needs of investors for information linking the financial elements to environmental and social aspects, and introducing governance in decision-making to clarify sustainability factors, create economic value, strike a balance between financial and nonfinancial performance indicators and provide information on the methods in which the management exercises its daily business (Mohammad, Abdul Jaleel, 2018).

To date, the researcher is not aware of any research that addresses the impact of integrated reporting disclosure on the financial performance in Palestine. This study will examine these concepts and their applicability in Palestine, with the aim of identifying the impact of integrated reporting on financial performance.

\section{Developing Hypothesis}

A performance index of integrated reporting was developed identifying the impact of disclosure of integrated reporting on the financial performance measured through ROA, ROE and EPS of Palestinian companies listed in the PEX. The index consists of the eight elements of integrated reports: organizational overview and external environment, governance, business model, risks 
Vol. 6, No.02; 2022

ISSN: $2456-7760$

and opportunities, strategy and resource allocation, performance, outlook, and basis of preparation and presentation. The researcher applied the multiple linear regression model to study the impact of all the elements of disclosure of integrated reports on ROA, ROE and the EPS.

\section{1- Return on Assets}

Return on assets measures the extent to which management can make profits from the available funds. Hence, it expresses the relation between accounting profits and the amount of funds available to the company's management, irrespective of the way the company financed its assets. Accordingly, ROA only reflects the impact of the operational and investment activities and does not reflect the financing of activities (Khalaileh, 2021).

Prior to applying the multiple linear regression model and to respond to the major study hypothesis, the correlation coefficient among the study variables in the correlation matrix were calculated to study the nature of the relations between the study variables.

H1:

$$
\begin{aligned}
R O A_{i}=B_{0}^{1} & +B_{1}^{1} X_{1 i}+B_{2}^{1} X_{2 i}+B_{3}^{1} X_{3 i}+B_{4}^{1} X_{4 i}+B_{5}^{1} X_{5 i}+B_{6}^{1} X_{6 i}+B_{7}^{1} X_{7 i} \\
& +B_{8}^{1} X_{8 i}+u_{i}^{1}
\end{aligned}
$$

There is no statistically significant impact for the integrated reporting disclosure on the financial performance measured through ROA on the Palestinian companies listed in PEX.

\section{2- Return on Equity}

The ROE measures the rate of return on equity that the shareholders make on the money they invested in the company's capital. A higher ROE reflects the management's efficiency in making investment and operational decisions (Gharaibeh, Ja'afar, 2008).

Prior to implementing the multiple regression analysis to respond to the study's second major hypothesis, the correlation coefficient among the study variables in the correlation matrix were calculated to study the nature of relations between the study variables.

$\mathrm{H} 2:$

$$
\begin{gathered}
E P S_{i}=B_{0}^{2}+B_{1}^{2} X_{1 i}+B_{2}^{2} X_{2 i}+B_{3}^{2} X_{3 i}+B_{4}^{2} X_{4 i}+B_{5}^{2} X_{5 i}+B_{6}^{2} X_{6 i}+B_{7}^{2} X_{7 i} \\
+B_{8}^{2} X_{8 i}+u_{i}^{2}
\end{gathered}
$$

There is no significant statistical impact for the integrated reporting disclosure on the financial performance measured through ROE on the Palestinian companies listed in PEX.

3-Earnings per Share

EPS expresses the aggregate performance of the company, reflecting the company's efficiency in using the available assets and resources. It plays an important role in identifying the share price (Shnin, Zaqoun, 2015). 
Prior to implementing the multiple regression analysis and to respond to the second major study hypothesis, the correlation coefficient among the study variables in the correlation matrix were calculated to study the nature of relations between the study variables.

$\mathrm{H}: 3$

$$
\begin{aligned}
R O E_{i}=B_{0}^{3} & +B_{1}^{3} X_{1 i}+B_{2}^{3} X_{2 i}+B_{3}^{3} X_{3 i}+B_{4}^{3} X_{4 i}+B_{5}^{3} X_{5 i}+B_{6}^{3} X_{6 i}+B_{7}^{3} X_{7 i} \\
& +B_{8}^{3} X_{8 i}+u_{i}^{3}
\end{aligned}
$$

There is no significant statistical impact for the integrated reporting disclosure on the financial performance measured through EPS on Palestinian companies listed in the PEX.

\section{Methodology}

1- Data collection

The study's population represented all Palestinian companies listed in PEX as of end of 2020, including 47 companies distributed over five sectors: investment companies (10), banks (7), insurance (7), manufacturing (13) and services (9). However, the study included 46 companies, since one investment company Al-Aqariya Trading Investment Co., was excluded because some of the data necessary to measure and calculate the research variables was either unavailable or incomplete. Data was gathered from company websites as well as the PEX. 


\section{The Independent Variable: \\ Accounting Disclosure of Integrated Reports}

\section{The Auxiliary Variable: Financial Performance}

\begin{tabular}{|l|}
\hline Return on Assets \\
\hline Return on Equity \\
\hline Earnings per Share \\
\hline \\
\hline
\end{tabular}

Risks and Opportunities

Strategy and Resource Allocation

Performance

Outlook

Basis of Preparation and

Presentation

\section{Diagram (1.1): Study Variables (independent and auxiliary)}

Source: Developed by the researcher in accordance with the study objectives

The study variables consist of examining the impact of disclosure of integrated reports on the financial performance of Palestinian companies listed in the 2020 PEX by conducting a financial statistical analysis to clarify its impact. It is at first necessary to examine the behavior of the study's independent and auxiliary variables by consecutively examining them from an analytical and descriptive perspective. 


\section{International Journal of Economics, Business and Management Research}

Vol. 6, No.02; 2022

ISSN: $2456-7760$

Independent variables: includes the disclosure elements in integrated reports. The study consisted of eight disclosure elements in integrated reports as independent variables, measured through a set of indicators that the researcher developed based on prior indicators from earlier studies, in addition to new indicators for each element.

Study data was collected using secondary sources, represented by the financial and non-financial data of the companies that constitute the study sample. The data was obtained from annual reports published in PEX website, and a review of their respective websites. The data related to the independent variable was collected utilizing an index, which the researcher developed and designed specifically for this purpose using indicators from previous research and customizing them to suit the study subject and the content of integrated reports, in accordance with IIRC framework. The aim is to obtain the necessary data to examine the study's hypotheses. To obtain this data, the researcher read the annual financial reports of each company, adopting the "dummy variable" method: if the company discloses (1) indicator either directly or indirectly, it receives (1) in its annual report index, otherwise, if it does not disclose any indicators it receives $(0)$. The disclosure rate of companies to the disclosure elements in integrated reporting was calculated using the following equation:

Rate of company disclosure of integrated reports $=$ total indices $\times 100$

Number of indices

Regarding the auxiliary variable, special equations were applied for each index using the figures reported in the financial report.

In terms of the statistical methods adopted in responding to the study hypotheses, the study adopts the multiple linear regression analysis, through building (3) models to respond to the major study hypotheses in the following manner:

$$
\begin{aligned}
R_{0} A_{i}=B_{0}^{1} & +B_{1}^{1} X_{1 i}+B_{2}^{1} X_{2 i}+B_{3}^{1} X_{3 i}+B_{4}^{1} X_{4 i}+B_{5}^{1} X_{5 i}+B_{6}^{1} X_{6 i}+B_{7}^{1} X_{7 i} \\
& +B_{8}^{1} X_{8 i}+u_{i}^{1} \\
E P S_{i}=B_{0}^{2}+ & B_{1}^{2} X_{1 i}+B_{2}^{2} X_{2 i}+B_{3}^{2} X_{3 i}+B_{4}^{2} X_{4 i}+B_{5}^{2} X_{5 i}+B_{6}^{2} X_{6 i}+B_{7}^{2} X_{7 i} \\
& +B_{8}^{2} X_{8 i}+u_{i}^{2} \\
R O E_{i}=B_{0}^{3} & +B_{1}^{3} X_{1 i}+B_{2}^{3} X_{2 i}+B_{3}^{3} X_{3 i}+B_{4}^{3} X_{4 i}+B_{5}^{3} X_{5 i}+B_{6}^{3} X_{6 i}+B_{7}^{3} X_{7 i} \\
& +B_{8}^{3} X_{8 i}+u_{i}^{3}
\end{aligned}
$$


Whereby the variables were represented by:

$\begin{array}{ll}X_{1} & \text { Organizational Overview and External Environment } \\ X_{2} & \text { Governance } \\ X_{3} & \text { Business Model } \\ X_{4} & \text { Risks and Opportunities } \\ X_{5} & \text { Strategy and Resource Allocation } \\ X_{6} & \text { Performance } \\ X_{7} & \text { Outlook } \\ X_{8} & \text { Basis of Preparation and Presentation } \\ R O A & \text { Return on Assets } \\ R O E & \text { Return on Equity } \\ E P S & \text { Earnings per Share }\end{array}$

While the regression coefficients were represented as B1, B2 and B3, the error term was represented by Ui

\section{Findings and Discussion:}

The findings reveal that the average disclosure rate of integrated reports for Palestinian companies listed in the 2020 PEX amounts to (76.7\%). Moreover, we note that the sector that discloses the most integrated reports is the banking sector (90.3\%), while investment companies have the lowest reporting rate of $(67.6 \%)$.

Regarding disclosure by the Palestinian companies listed in the 2020 PEX, of the eight elements of integrated reports included in this study, the findings reveal that the highest rate of disclosure among the Palestinian companies relates to risks and opportunities (94.6\%), followed by the basis of preparation and presentation $(92.7 \%)$, while the average disclosure rate of Palestinian companies to the business model was the lowest (55.8\%). On the other hand, disclosure of the risks and opportunities held the highest average disclosure rate among companies from all sectors with the exception of the banking sector, in which disclosure of the basis of preparation and presentation achieved the highest average. 


\section{Descriptive statistics and inferential statistics}

The Pearson correlation coefficients between the elements of integrated reporting disclosure and the financial performance measured by the return on assets

\begin{tabular}{|c|c|c|c|c|c|c|c|c|c|}
\hline Variables & 1 & 2 & 3 & 4 & 5 & 6 & 7 & 8 & 9 \\
\hline 1-Return on assets & 1.00 & & & & & & & & \\
\hline $\begin{array}{l}\text { 2-Organizational } \\
\text { overview and external } \\
\text { environment }\end{array}$ & 0.16 & 1.00 & & & & & & & \\
\hline 3-Governance & $\begin{array}{l}0.25 \\
* *\end{array}$ & $\begin{array}{l}0.39 \\
* *\end{array}$ & $\begin{array}{l}1.0 \\
0\end{array}$ & & & & & & \\
\hline 4- Business model & $\begin{array}{l}0.22 \\
*\end{array}$ & $\begin{array}{l}0.53 \\
* *\end{array}$ & $\begin{array}{l}0.2 \\
1 *\end{array}$ & 1.00 & & & & & \\
\hline Risks and opportunities & -0.04 & $\begin{array}{l}0.65 \\
* *\end{array}$ & $\begin{array}{l}0.1 \\
2\end{array}$ & $0.37 * *$ & 1.00 & & & & \\
\hline $\begin{array}{l}\text { 5-Strategy and Resource } \\
\text { Allocation }\end{array}$ & $\begin{array}{l}0.20 \\
*\end{array}$ & $\begin{array}{l}0.63 \\
* *\end{array}$ & $\begin{array}{l}0.5 \\
3 * *\end{array}$ & $0.46 * *$ & $\begin{array}{l}0.38 \\
* *\end{array}$ & 1.00 & & & \\
\hline 6-Performance & $\begin{array}{l}0.37 \\
* *\end{array}$ & $\begin{array}{l}0.44 \\
* *\end{array}$ & $\begin{array}{l}0.9 \\
2 * *\end{array}$ & $0.26 * *$ & 0.18 & $\begin{array}{l}0.51 \\
* *\end{array}$ & 1.00 & & \\
\hline 7-Outlook & $\begin{array}{l}0.26 \\
* *\end{array}$ & $\begin{array}{l}0.47 \\
* *\end{array}$ & $\begin{array}{l}0.3 \\
7 * *\end{array}$ & $0.59 * *$ & $\begin{array}{l}0.24 \\
*\end{array}$ & $\begin{array}{l}0.48 \\
* *\end{array}$ & $\begin{array}{l}0.46 \\
* *\end{array}$ & 1.00 & \\
\hline $\begin{array}{l}\text { 8-Basis of Preparation } \\
\text { and Presentation }\end{array}$ & -0.01 & $\begin{array}{l}0.75 \\
* *\end{array}$ & $\begin{array}{l}0.2 \\
4 *\end{array}$ & $0.48 * *$ & $\begin{array}{l}0.84 \\
* *\end{array}$ & $\begin{array}{l}0.54 \\
* *\end{array}$ & $\begin{array}{l}0.29 \\
* *\end{array}$ & $\begin{array}{l}0.42 \\
* *\end{array}$ & 1.00 \\
\hline
\end{tabular}

The above matrix reveals no significant statistical impact for disclosure of integrated reports on the financial performance of the companies measured through ROA at significance level $(\alpha$ $=0.05$ ), which leads to acceptance of the first main hypothesis. The findings reveal a negative and statistically significant impact for disclosure of the governance framework on ROA at the significance level $(\alpha=0.05)$. When the disclosure rate of the governance framework for the company increases by $1 \%$, ROA decreases by (12.57). Moreover, the findings revealed a positive and statistically significant impact of the disclosure of companies of their performance on ROA at significance level $(\alpha=0.05)$. When the disclosure rate of the company's performance increases by $1 \%$, ROA increases by (16.31). The findings also reveal no impact for the following disclosure elements of integrated reports: organizational overview and external environment, business model, risks and opportunities, strategy and resource allocation, outlook and basis of preparation and presentation on ROA, as the value of the statistical significance for each element was higher than the significance level $(\alpha=0.05)$. 
The Pearson correlation coefficients between the elements of integrated reporting disclosure and the financial performance measured by the return on equity

\begin{tabular}{|c|c|c|c|c|c|c|c|c|c|}
\hline Variable & 1 & 2 & 3 & 4 & 5 & 6 & 7 & 8 & 9 \\
\hline $\begin{array}{l}\text { 1- Return on } \\
\text { Equity }\end{array}$ & 1.00 & & & & & & & & \\
\hline $\begin{array}{l}2- \\
\text { Organizational } \\
\text { overview and } \\
\text { external } \\
\text { environment }\end{array}$ & $0.25^{* *}$ & 1.00 & & & & & & & \\
\hline 3-Governance & $0.25^{* *}$ & $0.39^{* *}$ & 1.00 & & & & & & \\
\hline $\begin{array}{l}\text { 4-Business } \\
\text { Model }\end{array}$ & $0.36^{* *}$ & $0.53 * *$ & $0.21^{*}$ & 1.00 & & & & & \\
\hline $\begin{array}{l}\text { 5-Risks and } \\
\text { Opportunities }\end{array}$ & $0.25^{* *}$ & $0.65^{* *}$ & 0.12 & $0.37 * *$ & 1.00 & & & & \\
\hline $\begin{array}{l}\text { 6-Strategy and } \\
\text { Resource } \\
\text { Allocation }\end{array}$ & -0.06 & $0.63 * *$ & $0.53 * *$ & $0.46 * *$ & $0.38^{* *}$ & 1.00 & & & \\
\hline 7-Performance & $0.19^{*}$ & $0.44 * *$ & $0.92 * *$ & $0.26 * *$ & 0.18 & $0.51^{* *}$ & 1.00 & & \\
\hline 8-Outlook & $0.29 * *$ & $0.47 * *$ & $0.37 * *$ & $0.59 * *$ & $0.24^{*}$ & $0.48 * *$ & $0.46^{* *}$ & 1.00 & \\
\hline $\begin{array}{l}\text { 9-Basis of } \\
\text { preparation } \\
\text { and } \\
\text { presentation }\end{array}$ & 0.03 & $0.75^{* *}$ & $0.24^{*}$ & $0.48 * *$ & $0.84 * *$ & $0.54 * *$ & $0.29 * *$ & $0.42 * *$ & 1.00 \\
\hline
\end{tabular}

The findings in the table above indicate a significant statistical correlation between disclosure of integrated reports and financial performance of the companies measured through $\mathrm{ROE}$ at significance level $(\alpha=0.10)$, where the value of statistical significance accounts for $(0.091)$, which is lower than $(\alpha=0.10)$. This leads to rejection of the second major hypothesis. Moreover, the findings reveal a negative and statistically significant impact for disclosure of the governance framework on ROE at a significance level $(\alpha=0.05)$; therefore, whenever the disclosure rate of the company's governance framework increases by 1\%, ROE decreases by (27.771). Furthermore, the findings show a positive and statistically significant impact for the companies' disclosure of their performance on ROE at significance level $(\alpha=0.05)$, as the disclosure rate of 
the company's performance increases by $1 \%$, ROE increases by ( 41.025 ). The findings also revealed the lack of an effect for the following elements of disclosure of integrated reports: organizational overview and external environment, business model, risks and opportunities, strategy and resource allocation, outlook and basis of preparation and presentation, as the statistical significance for each of these was higher than the significance level $(\alpha=0.05)$.

The findings asserted that the elements of disclosure of integrated reports can altogether explain $41.62 \%$ of the variance in ROE of the Palestinian companies listed in PEX.

The Pearson correlation coefficients between the elements of integrated reporting disclosure and the financial performance measured by the EPS.

\begin{tabular}{|c|c|c|c|c|c|c|c|c|c|}
\hline Variables & 1 & 2 & 3 & 4 & 5 & 6 & 7 & 8 & 9 \\
\hline $\begin{array}{l}\text { 1-Earnings per } \\
\text { Share }\end{array}$ & 1.00 & & & & & & & & \\
\hline $\begin{array}{l}\text { 2-Organizational } \\
\text { Overview and } \\
\text { External } \\
\text { Environment }\end{array}$ & 0.02 & 1.00 & & & & & & & \\
\hline 3-Governance & 0.16 & $0.39 * *$ & 1.00 & & & & & & \\
\hline $\begin{array}{l}\text { 4-Business } \\
\text { Model }\end{array}$ & 0.12 & $0.53^{* *}$ & $0.21 *$ & 1.00 & & & & & \\
\hline $\begin{array}{l}\text { 5-Risks and } \\
\text { Opportunities }\end{array}$ & -0.02 & $0.65^{* *}$ & 0.12 & $0.37 * *$ & 1.00 & & & & \\
\hline $\begin{array}{ll}\text { 6-Strategy } & \text { and } \\
\text { Resource } & \\
\text { Allocation } & \end{array}$ & $0.23 *$ & $0.63^{\text {** }}$ & $0.53^{* * *}$ & $0.46^{* *}$ & $0.38 * *$ & 1.00 & & & \\
\hline 7-Performance & $0.26^{* *}$ & $0.44 * *$ & $0.92^{* * *}$ & $0.26^{* *}$ & 0.18 & $0.51 * *$ & 1.00 & & \\
\hline - Outlook 8 & -0.06 & $0.47^{* *}$ & 0.37 ** & $0.59^{* *}$ & $0.24 *$ & $0.48 * *$ & $0.46^{* *}$ & 1.00 & \\
\hline $\begin{array}{l}9-\quad \text { Basis of } \\
\text { Preparation and } \\
\text { Presentation }\end{array}$ & -0.17 & $0.75^{* *}$ & $0.24 *$ & $0.48 * *$ & $0.84 * *$ & $0.54 * *$ & $0.29 * *$ & $0.42 * *$ & 1.00 \\
\hline
\end{tabular}

The findings in the table above reveal a statistically significant correlation between the disclosure of integrated reports and the financial performance of the companies measured by EPS at the significance level $(\alpha=0.05)$, as the statistical significance amounted to (0.04), which is lower than significance level $(\alpha=0.05)$. This data leads to rejection of the third major hypothesis. Moreover, the findings revealed: 
International Journal of Economics, Business and Management Research

Vol. 6, No.02; 2022

ISSN: $2456-7760$

- There is a statistically significant negative impact for the governance framework on EPS at significance level $(\alpha=0.05)$. As the rate of disclosure of the governance framework increases by $1 \%$, EPS decreases by (4.317).

- A statistically significant positive impact for the disclosure of strategy and resource allocation on EPS at a significance level $(\alpha=0.05)$. As the rate of disclosure of strategy and resource allocation increases by $1 \%$, EPS increases by (2.584).

- A statistically significant positive impact for the disclosure of the company's performance on EPS at a significance level of $(\alpha=0.05)$. As the rate of disclosure of performance increases by $1 \%$, EPS increases by (5.004).

- A statistically significant negative impact for the disclosure of the company's outlook on EPS at a significance level $(\alpha=0.05)$. As the rate of disclosure of the outlook increases by $1 \%$, EPS decreases by (1.546).

- A statistically significant negative impact for the disclosure of the company's basis of preparation and presentation on EPS at significance level $(\alpha=0.05)$. As the rate of disclosure of the basis of preparation and presentation increases by 1\%, EPS decreases by (5.488).

On the other hand, the findings revealed no impact for the following elements of the disclosure of integrated reports: organizational overview and external environment, business model, and risks and opportunities on EPS. The statistical significance for each of these is higher than the significance level $(\alpha=0.05)$. The findings confirm that the disclosure elements of integrated reports altogether are able to explain (46.61\%) of the variance in EPS of the Palestinian companies listed in PEX.

\section{Regression Analysis}

The findings of the multi-linear regression analysis (regression model 1) for the study of the impact of the disclosure of integrated reports on the financial performance measured through ROA

\begin{tabular}{|l|l|l|l|l|}
\hline Independent variables & B & $\begin{array}{l}\text { Standard } \\
\text { error }\end{array}$ & t- value & VIF \\
\hline Fixed regression & 2.322 & 3.197 & 0.73 & \\
\hline $\begin{array}{l}\text { Organizational Overview and External } \\
\text { Environment }\end{array}$ & 1.678 & 4.389 & 0.38 & 3.07 \\
\hline Governance & $-12.572^{* *}$ & 5.942 & -2.12 & 7.54 \\
\hline Business Model & 3.067 & 3.716 & 0.83 & 1.82 \\
\hline Risks and Opportunities & 0.474 & 8.755 & -0.05 & 3.86 \\
\hline Strategy and Resource Allocation & 2.366 & 3.084 & 0.77 & 2.20 \\
\hline Performance & $16.315^{* *}$ & 5.619 & 2.90 & 7.76 \\
\hline Outlook & 0.287 & 3.034 & 0.09 & 1.98 \\
\hline Basis of Preparation and Presentation & -7.593 & 9.509 & -0.80 & 5.16 \\
\hline R Square=0.2538; P-value=0.23 ; F-test=1.39 & & & \\
\hline
\end{tabular}


The findings of the multi linear regression analysis (regression model 2) for the study of the impact of the disclosure of integrated reports on the financial performance measured through ROE

\begin{tabular}{|l|l|l|l|l|}
\hline Independent variables & $\mathbf{B}$ & $\begin{array}{l}\text { Standard } \\
\text { error }\end{array}$ & t- value & VIF \\
\hline Fixed regression & 4.104 & 5.207 & 0.79 & \\
\hline $\begin{array}{l}\text { Organizational Overview and } \\
\text { External Environment }\end{array}$ & 11.539 & 9.283 & 1.24 & 3.07 \\
\hline Governance & $-27.771^{* *}$ & 11.721 & -2.37 & 7.54 \\
\hline Business Model & 6.759 & 6.788 & 1.00 & 1.82 \\
\hline Risks and Opportunities & -13.589 & 14.335 & -0.95 & 3.86 \\
\hline Strategy and Resource Allocation & -2.763 & 6.045 & -0.46 & 2.20 \\
\hline Performance & $41.025^{* *}$ & 11.898 & 3.45 & 7.76 \\
\hline Outlook & -1.705 & 5.237 & -0.33 & 1.98 \\
\hline $\begin{array}{l}\text { Basis of Preparation and } \\
\text { Presentation }\end{array}$ & -6.391 & 16.493 & -0.39 & 5.16 \\
\hline R Square=0.4162; P-value=0.091 ; F-test=1.89 & \multicolumn{2}{|l}{} \\
\hline
\end{tabular}

The findings of the multi linear regression analysis (regression model 3) for the study of the impact of the disclosure of integrated reports on the financial performance measured through EPS

\begin{tabular}{|l|l|l|l|l|}
\hline Independent variables & $\mathbf{B}$ & $\begin{array}{l}\text { Standard } \\
\text { error }\end{array}$ & t- value & VIF \\
\hline Fixed regression & 1.024 & 0.985 & 1.04 & \\
\hline $\begin{array}{l}\text { Organizational Overview and } \\
\text { External Environment }\end{array}$ & -0.384 & 1.274 & -0.30 & 3.07 \\
\hline Governance & $-4.317^{* *}$ & 1.638 & -2.64 & 7.54 \\
\hline Business Model & 1.302 & 0.888 & 1.47 & 1.82 \\
\hline Risks and Opportunities & 3.048 & 2.471 & 1.23 & 3.86 \\
\hline Strategy and Resource Allocation & $2.584^{* *}$ & 1.075 & 2.40 & 2.20 \\
\hline Performance & $5.004^{* *}$ & 1.696 & 2.95 & 7.76 \\
\hline Outlook & $-1.546^{*}$ & 0.777 & -1.99 & 1.98 \\
\hline $\begin{array}{l}\text { Basis of Preparation and } \\
\text { Presentation }\end{array}$ & $-\mathbf{- 5 . 4 8 8 * *}$ & 2.640 & -2.08 & 5.16 \\
\hline R Square=0.4661; P-value=0.0437 $; \mathbf{F - t e s t = 2 . 2 7}$ & & & \\
\hline
\end{tabular}

\section{Conclusions}

1- The findings indicated that the disclosure of integrated reports for the Palestinian companies listed in PEX does not affect the financial performance measure through ROA. The findings also revealed that the disclosure of the companies' governance 


\section{International Journal of Economics, Business and Management Research}

Vol. 6, No.02; 2022

ISSN: $2456-7760$

framework negatively affects ROA, while the disclosure of performance positively affects ROA.

The researcher's explanation of this outcome is that the financial performance in general, and the net profits in particular, were low for most companies during 2020 due to the global COVID-19 pandemic, as the net profit of (7) companies was negative during 2020, including (3) companies operating in the investment sector. For example, the Sanad Construction Resources Company losses amounted to about US\$ 9,700,000, while Palestine Real Estate Investment Company (PRICO) lost around US\$ 5,000,000. Moreover, the profits of three companies did not exceed 50,000 ILS, while the profits of three others did not exceed 500,000 ILS towards the end of 2020. The researcher is keen on applying the study on 2020 data as the subject of the study is new, especially in developing countries such as Palestine, Lebanon, Jordan, Saudi Arabi and others. It is also not binding to a specific law or standard. The researcher believes that this research is not applicable to past years as there was no integrated reporting of financial data and reports of companies, or the data was only partial. Most previous studies and research that addressed the subject of integrated reporting are recent as well and only cover the period between 2015-2020. This finding is in line with Abdul Al study (Abdul Al, 2017), which concluded that there is no relation between the financial performance measured through ROA and the disclosure of integrated reports. Similarly, the findings of the Buallay study (Buallay et al., 2020) confirmed the absence of any evidence that shows if integrated reporting becomes mandatory, then the performance shall improve generally at the financial, operational or market level. It also asserted that integrated reporting negatively affects the financial performance of Islamic banks, and the Tobins Q ratio, while it has no major impact on ROA. In this context, the (Ibrahim, 2019) study also confirmed a negative impact of the independent variable (disclosure of governance) and the financial performance of companies, as it leads to an decrease in ROA (Adegboyegun et al. 2020) as an indicator for financial performance. The study findings confirmed that integrated reporting has no major impact on the short-term performance of companies but it is strongly linked to long-term performance, as time passes.

2- The findings revealed a positive impact for the disclosure of integrated reporting on the financial performance of the Palestinian companies listed in the PEX measured by ROE. Moreover, the findings indicated that the companies' disclosure of the governance framework negatively impacts ROE. This findings did not agree with the (Buallay et al, 2020) study that asserted that integrated reporting negatively impacts the financial performance of Islamic banks and the Tobin's Q ratio, while it has no major impact on it in terms of ROE.

3- The study revealed that the disclosure of integrated reports at the Palestinian companies listed in PEX has a positive impact on the financial performance measured in EPS. It also revealed that the company's disclosure of each of the governance framework, outlook, basis for preparation and presentation has a negative impact on EPS, while the disclosure of performance and strategy and resource allocation has a positive impact on EPS. In this

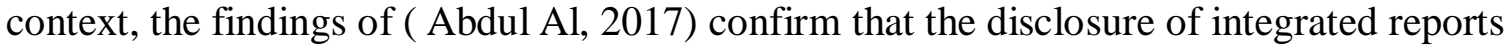
leads to increased trading of the companies' shares in the stock exchanges, while (Barth et 


\section{International Journal of Economics, Business and Management Research}

Vol. 6, No.02; 2022

ISSN: $2456-7760$

al, 2016) affirmed a positive relation between integrated reports, share liquidity and the value of the company.

\section{References}

\section{Arabic references}

Ibrahim, Tareq (2019): أثر الإفصاح الدحاسبي عن تقارير الأعمال الهتكاملة على الأداء المالي والتتشيلي في الثركات (The impact of accounting disclosure of integrated business reports on the financial and operational performance of shareholding companies listed in the Egyptian Exchange), The Egyptian Academy of Computers and Information and Technology Management, Tanta.

Khalaileh, Mahmoud (2001): العلاقة بين مؤشرات الأداء المحاسبية ومؤشرات الاداء السوقية (The relation

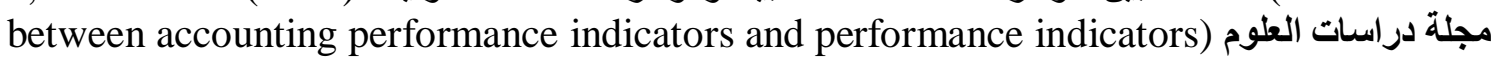
الادارية, Book No. 28, Issue No. 1.

Gharaibeh, Fawzi; Ja'afar, Daoud (2008): مضمون الارقام المحاسبية من المعلومات في الثركات المساهمة (The content of information in the accounting figures of the Jordanian shareholding companies), Abhath Al-Yarmouk Humanities and Social Science, Book No. 4, Issue No. 1.

Sha'aban. Samir (2019): دور المحاسبة عن المسؤولية الاجتماعية للشركات في تعزيز جودة تقارير الأعمال المتكاملة (The role of accounting for corporate social responsibility in enhancing the quality of integrated business reports), Master's Thesis, Tikrit University, Iraq.

Shineen, Abdul Nour; Zarqoun, Mohammad (2015): دراسة قدرة المؤشرات التقليدية والحديثة على تفسير الأداء المالي للمؤسسات الاقتصادية المسعرة في البورصة

(Studying the ability of conventional and modern indicators to explain the financial performance of economic enterprises listed in the stock exchange) Journal of Quantitative Economics Studies, Issue No. 1.

Abdul Al, Mahmoud (2017) : محددات الإفصاح بتقارير الأعمال المتكاملة وأثر ذلك على نشاط سوق الأوراق : المالية. on the activity of the stock markets). مجلة الفكر المحاسبي، Issue No 4، Section 2

Mohammad, Mohammad; Abdul Jaleel, Mohammad (2018): أثر توفير المعلومات بتقارير الاعمال بنجاح (The impact of making information available in business reports on the success of the competitive strategy), Journal of Economic, Administrative, and Legal Sciences, Book No. 2, Issue no. 3.

Yousef, Jamal (2015): التقارير المتكاملة كمذل للتغيير الداخلي في الثركات المساهمة المصرية. (The integrated

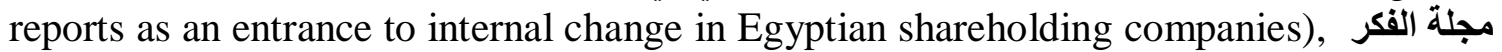
المحاسبي , Issue No. 2, Section 2.

\section{English References}

Adegboyegun' A c et al. (2020): Integrated Reporting and Corporate Performance In Nigeria: Evidence From The Banking Industry. cogent Business \& Management، 7:1.

Barth، Mary، et al. (2016): The Economic Consequences Associated with Integrated Report Quality: Early Evidence from a Mandatory Setting. University of Pretoria، unpublished working paper. 
Bouma، F. (2015): Determinants for the voluntary adoption of Integrated Reporting \& its impact on CSR disclosure: A case study، University of Amsterdam.

Buallay, et al., (2020): Integrated Reporting and Performance: a Cross-country Comparison of GCC Islamic and Conventional Banks. Journal of Islamic Marketing.

Burke، Jenna. Clark, Cynthia (2016): The Business Case For Integrated Reporting: Insights From Leading Practitioners، Regulators، and Academics. Journal of business horizons.

Eccles، G. et al. (2014): Market Interest in no Financial Information. Harvard Business School، Working Paper' www.hbs.edu

Eccles، Robert. Saltzman، Daniela، (2011): Achieving Sustainability through Integrated Reporting.

International Integrated Reporting Council (IIRC), (2015): Applying the integrated reporting concept of "capitals" in the banking industry. IR Banking Network Paper Series. 